\title{
INHERITANCE TYPE OF THE LEAVES AND PRODUCTIVITY INDEFERENT GENOTYPES OF PEA (PISUM SATIVUM L.)
}

Kosev Valentin Ivanov

Institute of Forage Crops, Bulgaria, Pleven

The way of inheritance type of the pea leaves is a parameter of study in this investigation. Bulgarian and foreign varieties and their hybrids with different quality and quantity traits are used. Biological and agronomic characteristics are worked out. In genotype's crossover between acacia and afila type of the leaves is observed double recessive inheritance on pleiofila and monogenetic recessive on afila type. Do not established inter-allel interactions of the genes determined type of the leaves in investigated forms. A large diversity for different traits is received in hybrid populations. The pleiofila hybrids represent selection interest due to their high productivity of pod and seeds per plant that is prerequisite for future selection work.

\section{Pea, inheritance, genotype, type of leaves, productivity, selection}

\section{Introduction}

Among the most significant legumes is pea (Pisum sativum L.), a true multi-functional crop that may be used as green forage, forage meal, silage, haulage, [1]. Pea has also been a subject of genetic investigation since the experiments by Thomas Andrew Knight in the 1790s and Gregor Mendel in 1860s [2, 3].The leaves in most legume species are compound [4]. Pea, with its pinnately compound leaf consisting of basal, foliaceous stipules, proximal leaflets and distal tendrils, serves as a model species for understanding compound leaf development [5].

The development of leaflets and tendrils in pea is basically determined by two genes, $A F I$ LA ( $a f)$ on LG I and CLAVICULA $(t l)$ on LG "V". Basically, there are four main phenotypes determined by $a f$ and $t l$ genes: wild type (AfAf TlTl), with two or three pairs of leaflets and odd number of tendrils; afila (afaf TlTl)y; tendril-less (AfAf tltl); afila-tendril-less (afaf tltl). The phenotypes afila (afaf $T l T l$ ) are characterized with this that all leaflets are transformed in tendrils only [4], tendril-less (AfAf tltl), with leaflets only [6]. The double recessive genotypes (afaf tltl) are with compound leaf with tendrils ending and small leaflets [7].

According to Goldman and Gritton [8] and Heath and Hebblethwaite [9] the normal type (AfAf TlTl) leaves are favorable for reduction on sowing, overshadowing of the plants and premise for growth on places with more pathogens and lower lodging resistance.

Purpose. The objective of this study was to determine the biological possibilities and be done economical characteristic of hybrids with different type of leaves.

\section{Material and method}

The experimental study was conducted during the 2009-2012 period in second experimental field of the Institute of Forage Crops, Pleven. Done was hybridization between Bulgarian (Kerpo) and foreign (Usatii 90 and Fenn) pea varieties with alternative traits. In the research studied was the inheritance on type of leaves. In the hybridization were included varieties with different types of compound leaves - normal; afila and acacia (fig. 1). The castration and the pollination of the flowers were done by hand in 2009 at field conditions. The parental forms and first $\left(F_{1}\right)$ and next generations were sown on row spacing $11 \mathrm{~cm}$ and distance in row $5 \mathrm{~cm}$. Hand planting was applied with depth of sowing, $5 \mathrm{~cm}$. The forage pea was grown by approved technology of the Institute of forage Crops - Pleven. Done was biological and economical characteristic of $F_{2}$ hybrids and varieties. Analyzed were, the following quantitative traits: plant height (cm); number of pods per plant; seeds per plant; 1000 seeds mass $(\mathrm{g})$. 


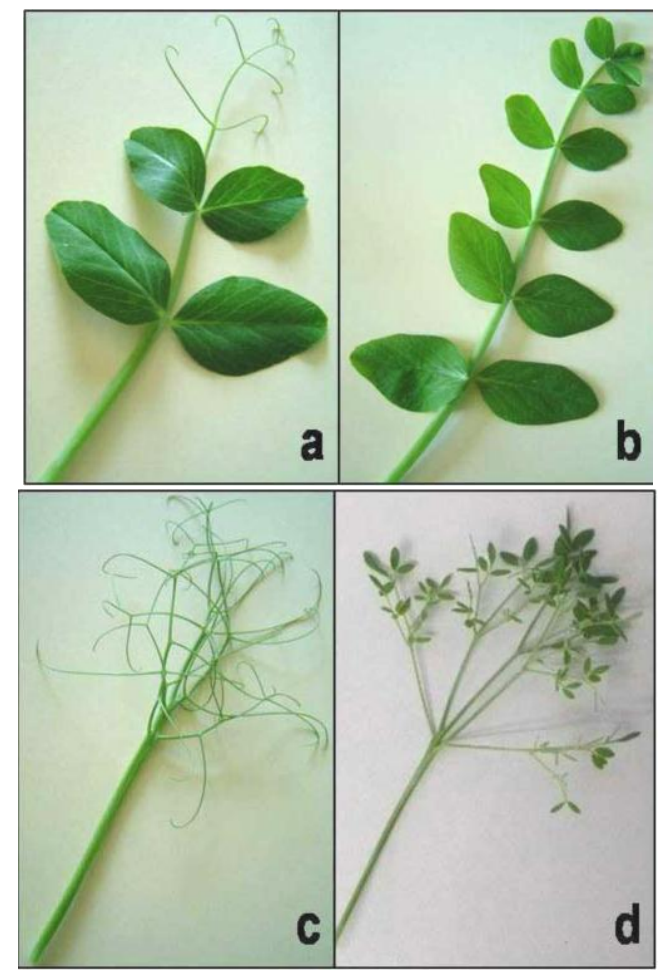

Fig. 1. Basic pea leaf types, regarding leaflets and tendrils:

(A) wild type, (B) tendrilless, (C) afila, (D) afila-tendril-less, Mikić et al.[11]

The genetically analysis of the distribution was done in $\mathrm{F}_{2}$. The statistical estimate of the character inheritance of trait-"shape of the leaves" was done with method $\mathrm{X}^{-2}$ (Генчев и др.) [12].

\section{Results and discussion}

At crossing of the varieties with acacia type of leaves (Fenn) with afila type (Usatii 90) in first generation, all plants were with normal leaves (fig. 2 A).

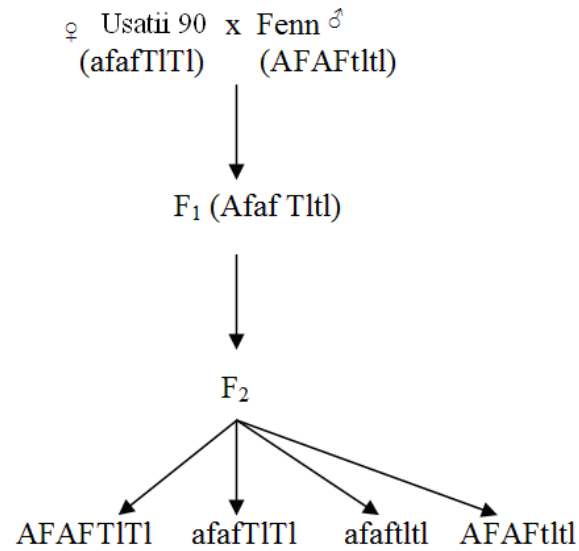

A

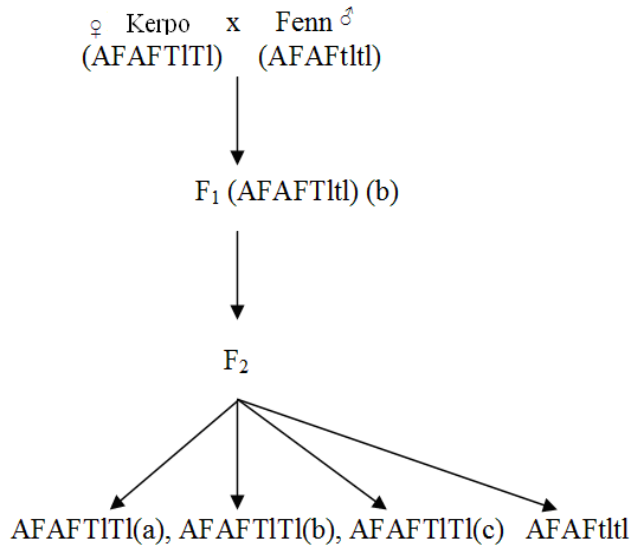

B

Fig.2. Scheme of the studied genotypes - A- Usatii 90 x Fenn; B- Kerpo x Fenn

The observed distribution in $\mathrm{F}_{2}$ was such that, the normal leaves were dominants. In the generation $\mathrm{F}_{2}$ (table 1) from all 368 plants 200 were with normal type of leaves, 65 with acacia type, 74 with afila type and 29 with pleiofila. 
Table 1

Inheritance type of the leaves at Pisum sativum

\begin{tabular}{|c|c|c|c|c|c|}
\hline \multirow{2}{*}{ Leaf Type } & \multicolumn{3}{|c|}{ Segregation } & \multirow{2}{*}{$X^{2}$} & \multirow{2}{*}{$\mathrm{P}$} \\
\hline & Experimental & Theoretical & Total & & \\
\hline \multicolumn{6}{|c|}{ Usatii 90 x Fenn } \\
\hline normal & 200 & 207 & \multirow{4}{*}{368} & \multirow{4}{*}{2.4} & \multirow{4}{*}{$50-20$} \\
\hline afila & 74 & 69 & & & \\
\hline acacia & 65 & 69 & & & \\
\hline pleiofila & 29 & 23 & & & \\
\hline \multicolumn{6}{|c|}{ Kerpo x Fenn } \\
\hline normal & 251 & \multirow{4}{*}{264} & \multirow{5}{*}{352} & \multirow{5}{*}{2.6} & \multirow{5}{*}{$20-5$} \\
\hline with 6 leaflets & 194 & & & & \\
\hline with 8 leaflets & 41 & & & & \\
\hline with 10 leaflets & 16 & & & & \\
\hline acacia & 101 & 88 & & & \\
\hline
\end{tabular}

Factual ratio does not contradict on accepted hypothesis that distribution is in ratio 9:3:3:1. The direction of crossing does not influence on distribution of this trait. Mono-genetic recessive inheritance of afila type was confirmed as well by other authors [13].

At Kerpo x Fenn (fig. 2 B) in $\mathrm{F}_{1}$ all plants were with normal leaves (8 leaflets), in $\mathrm{F}_{2}$ from 352 plants with normal leaves are 251 (194 plants are with 6 leaflets; 41 with 8 and 16 with 10). In this cross the ratio of the plants with different type of leaves in $F_{2}$ correspond on monohybrid distribution (Table 1).

Атанасова and Михов [14] established activity on dominant epistasis in hybridization of parents with normal ant pleiofila leaves, as considered that the genetic cleanness of the parent's forms proves essential influence on the interaction of the genes determining type of the leaves. After careful study on effects of $A f$ and $T L$ genes in the different forms of the leaves of pea [15] conclude that, through the effects of these genes and interaction between them is not possible to be explained fully the inheritance type of the leaves. These genes influence on the form of leaf overall length. The gene $A f$ decrease their influence from base to top of the leaf. The influence on $T l$ gene increases in the same direction (fig. 3).

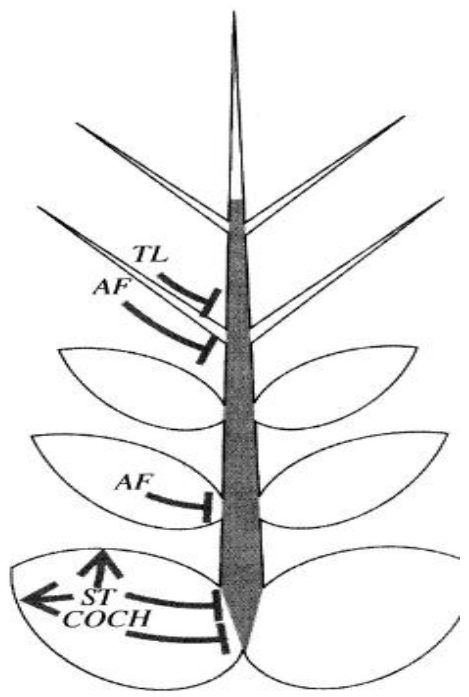

Fig. 3. Scheme of the genetically control of development of leaves in Pisum sativum (Синюшин, Гостимский [16].

The results of biometric measures in the investigation done about spring varieties and hybrids, show differences in biological and economical qualities of the genotypes with different form of the leaves (fig. 4). 


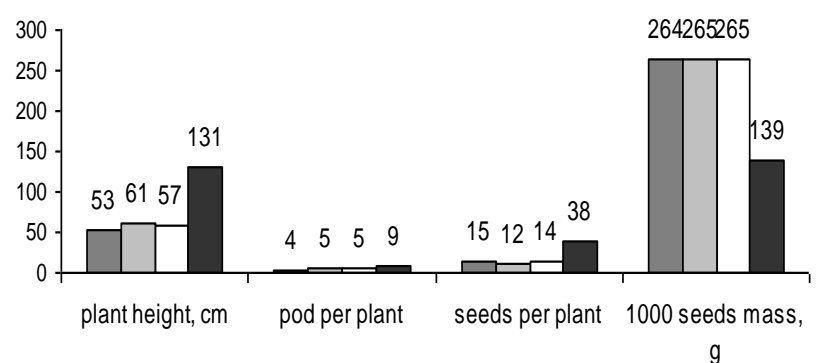

$\square$ Kerpo $\square$ Kristal $\square$ Normal leaves $\square$ pleiofila type

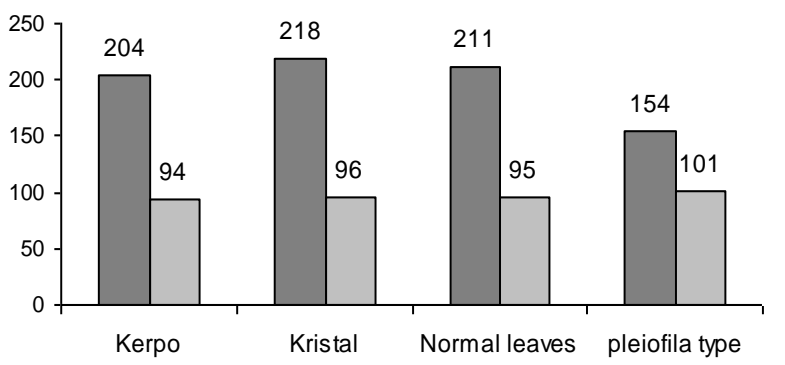

$\square$ Grain yield, kg.da-1 $\square$ growth period, days

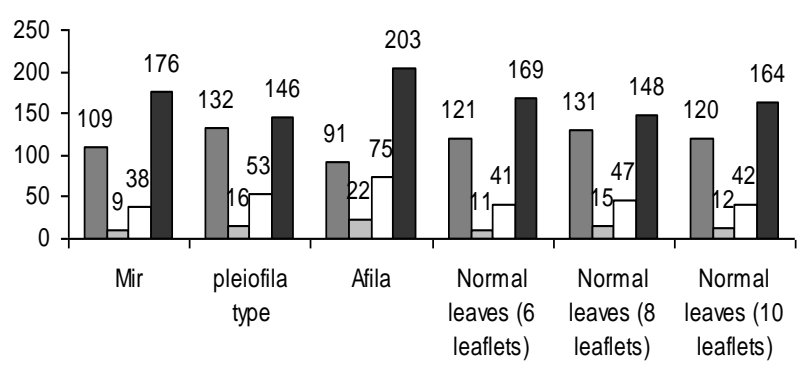

$\square$ plant height, $\mathrm{cm} \square$ pod per plant $\square$ seeds per plant $\square 1000$ seeds mass, $\mathrm{g}$

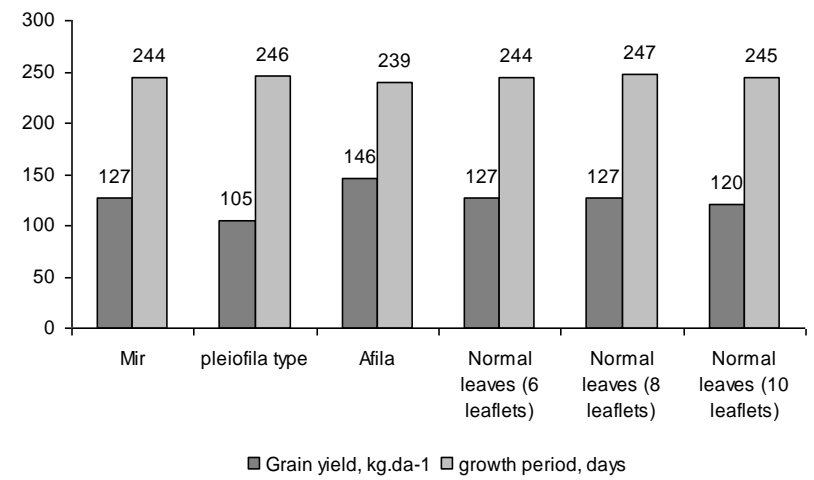

Fig. 4. Comparison of the investigated traits in the varieties and hybrids

According to the data, height of the plant, pods and seeds per plant priority have pleiofila hybrids $(131 \mathrm{~cm} ; 9 ; 38)$, followed with the varieties and the hybrids with normal leaves that showed the higher values of 1000 seeds mass (264-265 g.). This reveals the opportunity for these forms to be included in selection programs for transfer of their productive potential in the new hybrids.

The genotypes with normal leaves are characterized as more productive (Kristal -218 $\mathrm{kg} / \mathrm{da}$; Kerpo $-204 \mathrm{~kg} / \mathrm{da}$; hybrids $-211 \mathrm{~kg} / \mathrm{da}$ ) and early ripeness with shorter vegetation period (from 94 to 96 days), than pleiofila types (154 kg/da; 101 days). In winter form also is observed diversity at the studies traits.

At a height of the plant with highest values are pleiofila plants $(132 \mathrm{~cm})$ and these with normal leave generate 8 leaflets $(131 \mathrm{~cm})$. The shortest are plant type afila $(91 \mathrm{~cm})$ but they are with the better productive opportunities on pods (22) and seeds (75) per plant as well as a 1000 seeds mass (203 g). In relation with these traits pleiofila genotypes exceed the plants with normal leaves.

With higher grain yields (146 kg/da) and longer ripeness (239 days) than other are afila forms, followed by variety Mir and hybrids with normal type of leaves (127 kg/da; 244 days). Hybrids with 8-10 leaflets are with lower grain yields and with longer vegetative period.

There are different opinions about the advantages and defects on pleiofila plants. In the same time these plant types are investigated on a small scale in selection aspect. The reduced area of a leaf in afila plants permits infiltrating of more light to the lower leaves. This contributes on decrease of the diseases at pea. The transpiration is weaker in them and they are easily readjusted to the dry climate. On a result in the very bifurcate tendrils afila, the plants are with high lodging resistance, which facilitates their mechanized gathering.

Contradictory are the opinions about productive potentials on the afila plants. Goldenberg $[17,18]$ reports that the productivity between afila and normal forms is similar. Cardi et al. [19] and Ali et al. [20] ascertain the productiveness at afila types is reduced in the result of pods number and fertile nods per plant. 
Conclusions: In genotype's crossover between acacia and afila type of the leaves is observed double recessive inheritance on pleiofila and monogenetic recessive on afila type. Do not established inter-allel interactions of the genes determined type of the leaves in investigated forms.

A large diversity for different traits is received in hybrid populations.

The pleiofila hybrids represent the selection interest due to their high productivity of pod and seeds per plant that is prerequisite for future selection work.

\section{References}

1. Mihailović V. Leaf type and grain yield in forage pea / V. Mihailović, A. Mikić // Genet. Beogr. - 2004. - 36(1). - P. 31-38.

2. Ellis T. H. N. Approaches to the isolation of genes of agronomic importance in pea / T. H. N. Ellis // Field Veg. Crop. Res. - 2007. - 44(II). - P. 45-47.

3. Ellis T. H. N. Legume genetics and breeding: the example of pea / T. H. N. Ellis // Grain Legum. - 2009. - 51. - P. 14-15.

4. Lewis G. P. Legumes of the world / G. P. Lewis, B. Schrire, B. Mackinder, M. Lock. - 2005. - Kew Publishing, Richmond.

5. Yaxley J. L. Leaf and flower development in pea (Pisum sativum L.): Mutants cochleata and unifoliata / J. L. Yaxley, W. Jablonski, J. B. Reid // Ann. Bot. - 2001. - 88. - P. 225-234.

6. The control of pinna morphology in wild type and mutant leaves of the garden pea (Pisum sativum L.) / [B. Lu, P. Villani, J. Watson, D. DeMason, T. Cooke] // International journal of Plant science. - 1996. - 157. - P. 659-673.

7. White O. Studies of inheritance in pisum. II. The present state of knowledge of heredity and variation in peas / O. White // Proc Am Philos Soc. - 1917. - 56. - P. 487-588.

8. Marx G. A suite of mutants that modify pattern formation in pea leaves / G. Marx // Plant Mol Biol Rep. - 1978. - 5. - P. 311-335.

9. Goldman I. Evalutionof the afila-tendriled acacia (afaf-tactac) pea folage type under minimal competition / I. Goldman, E. Griton // Crop Science. - 1992. - 32. - P. 851-855.

10. Heath M. Agronomic problems associated with the pea crop / M. Heath, P. Hebblethwaite // [In: P. D. Hebblethwaite et al. (ed.)]. - The pea crop: A basis for improvement. Butterworths. London, 1985.

11. Genetic background and agronomic value of leaf types in pea (Pisum sativum) / [A. Mikić, V. Mihailović, B. Ćupina,V. Kosev,T. Warkentin, K. McPhee, M. Ambrose, J. Hofer, N. Ellis] // Ratar. Povrt. Field Veg. Crop Res. - 2011.- 48. - P. 275-284.

12. Биометрични методи в растениевъдството, генетиката и селекцията / [Г. Генчев, Е. Маринков, В. Йовчева, И. Огнянова]. - Земиздат, София, 1975.

13. Blixt S. Mutation genetics in pisum / S. Blixt // Agri Hort. Gen. - 1972. - XXX. - P. 1-293.

14. Атанасова Д. Проучване върху наследяването на някои типове листа при граха. [«Растителния генофонд основа на съвременното земеделие»], (Садово, 13-14 юни 2007) / Д. Атанасова, М. Михов // - 2007. - Том 2-3. - Р. 163-166.

15. DeMason D. Genetic control of leaf development in pea (Pisum sativum L.) / D. DeMason, Ph. Villani // International journal of Plant Science. - 2001. - 162 (3). - P. 493-511.

16. Синюшин А. А. Достижения и перспективы использования гороха посевного (Pisum sativum) в качестве модельного объекта в генетике развития растений / A. А. Синюшин, С. А. Гостимский // Успехи современной биологии. - 2008. - Т. 128, № 6. P. 531-541.

17. Goldenberg J. Uield and green pea weight of afila mutant / J. Goldenberg // Pisum newsletter. $-1973 .-5 .-$ P. 5-6.

18. Goldenberg J. "Afila", a new mutation in pea (Pisum sativum L.) / J. Goldenberg // Bol. Genet. - 1965. - 1. - P. 27-28.

19. Cardi T. Allelic and nonallelic interactions of $a f$, st, and $t l$ genes in pea / T. Cardi, L. Frusciante, L. Monti // Crop Science. - 1987. - 27. - P. 852-856. 
20. Ali S. M. Current status and future strategy in breeding pea to improve resistance to biotic and abiotic stresses / S. M. Ali, B. Sharma, G. Ambrose // Pros. of 2-nd Int. [«Food Legume Res. Conf.»], (Cairo, Egypt, April 12-16, 1992). - Cairo, 1992.

\section{References (CBE/CSE)}

1. Mihailović V, Mikić A. Leaf type and grain yield in forage pea. Genet. Beogr. 2004; 36(1):31-38.

2. Ellis THN. Approaches to the isolation of genes of agronomic importance in pea. Field Veg. Crop. Res. 2007; 44(II):45-47.

3. Ellis THN. Legume genetics and breeding: the example of pea. Grain Legum. 2009; 51:14-15.

4. Lewis GP, Schrire B, Mackinder B, Lock M. Legumes of the world. Richmond: Kew Publishing; 2005.

5. Yaxley JL, Jablonski W, Reid JB. Leaf and flower development in pea (Pisum sativum L.): Mutants cochleata and unifoliata. Ann. Bot. 2001; 88:225-234.

6. Lu B, Villani P, Watson J, DeMason D, Cooke T. The control of pinna morphology in wild type and mutant leaves of the garden pea (Pisum sativum L.). International journal of Plant science. 1996; 157:659-673.

7. White O. Studies of inheritance in pisum. II. The present state of knowledge of heredity and variation in peas. Proc Am Philos Soc. 1917; 56:487-588.

8. Marx G. A suite of mutants that modify pattern formation in pea leaves. Plant Mol Biol Rep. 1978; 5:311-335.

9. Goldman I, Griton E. Evalutionof the afila-tendriled acacia (afaf-tactac) pea folage type under minimal competition. Crop Science. 1992; 32:851-855.

10. Heath M, Hebblethwaite P. Agronomic problems associated with the pea crop. In: PD Hebblethwaite et al., editors. The pea crop: A basis for improvement. London: Butterworths; 1985.

11. Mikić A, Mihailović V, Ćupina B, Kosev V, Warkentin T, McPhee K, Ambrose M, Hofer J, Ellis N. Genetic background and agronomic value of leaf types in pea (Pisum sativum). Ratar. Povrt. Field Veg. Crop Res. 2011; 48:275-284.

12. Genchev G, Marinkov E, Yovcheva V, Ognianova I. Biometric methods in plant production, genetics and breeding. Sofia: Zemizdat; 1975.

13. Blixt S. Mutation Genetics in Pisum. Agri Hort. Gen. 1972; XXX:1-293.

14. Atanasova D, Mikhov M. Study of inheritance type of the leaves in pea. In: Plant gene pool the basis of modern agriculture; 2007 Jun 13-14; Sadovo (Bulgaria); 2007; 2-3:163-166.

15. DeMason D, Villani Ph. Genetic control of leaf development in pea (Pisum sativum L.). International journal of Plant Science. 2001; 162(3):493-511.

16. Siniushin AA, Gostimskii SA. Achievements and prospects of garden pea as a model object in genetics of plant development. Uspekhi sovremennoy biologii; 2008; 128(6):531-541.

17. Goldenberg J. Uield and green pea weight of afila mutant. Pisum newsletter. 1973; 5:5-6.

18. Goldenberg J. "Afila", a new mutation in pea (Pisum sativum L.). Bol. Genet. 1965; 1:27-28.

19. Cardi T, Frusciante L, Monti L. Allelic and nonallelic interactions of af, st, and tl genes in pea. Crop Science. 1987; 27:852-856.

20. Ali SM, Sharma B, Ambrose G. Current status and future strategy in breeding pea to improve resistance to biotic and abiotic stresses. In: Pros. of 2-nd Int. Food Legume Res. Conf.; 1992 April 12-16; Cairo (Egypt); 1992. 


\section{INHERITANCE TYPE OF THE LEAVES AND PRODUCTIVITY IN DEFERENT GENOTYPES OF PEA (PISUM SATIVUM L.)}

Kosev Valentin Ivanov

Institute of Forage Crops, Pleven, Bulgaria

Purpose. The objective of this study was to determine the biological possibilities and be done economical characteristic of hybrids with different type of leaves.

Results. The way of inheritance type of the pea leaves is a parameter of study in this investigation. Bulgarian and foreign varieties and their hybrids with different quality and quantity traits are used. Biological and agronomic characteristics are worked out. In genotype's crossover between acacia and afila type of the leaves is observed double recessive inheritance on pleiofila and monogenetic recessive on afila type. Do not established inter-allel interactions of the genes determined type of the leaves in investigated forms. A large diversity for different traits is received in hybrid populations. The pleiofila hybrids represent selection interest due to their high productivity of pod and seeds per plant that is prerequisite for future selection work.

Pea, inheritance, genotype, type of leaves, productivity, selection

\section{УСПАДКУВАННЯ ТИПУ ЛИСТЯ І ПРОДУКТИВНОСТІ В РІЗНИХ ГЕНОТИПІВ ГОРОХУ (PISUM SATIVUM L.)}

Козев Валентин Іванов

Інститут кормових культур, Плевен, Болгарія

Метою даного дослідження було визначення біологічних можливостей та економічна характеристика гібридів з різним типом листя.

Результати. Об'єктом дослідження цієї роботи є успадкування типу листя у гороху. Вихідним матеріалом були болгарські та іноземні сорти і гібриди, які відрізнялися між собою за даною ознакою. Надано їх біологічну та агрономічну характеристику. При схрещуванні гороху з акацієподібними листочками і безлисточковими спостерігається кросинговер, що виражається через подвійне рецесивне успадкування багатолисточковості та моногенне рецесивне успадкування afila-типу (безлисточковість). Не встановлено міжалельну взаємодію генів певного типу листя в потомстві. Широке різноманіття за різними ознаками отримано в гібридних популяціях. Багатолисточкові гібриди представляють інтерес для селекції через їх високу продуктивність бобів та насіння, що $є$ передумовою для майбутньої селекційної роботи.

Горох, успадкування, генотип, тип листя, продуктивність, селекиія 